
cultures

Les cahiers de l'Acedle

17-1 | 2020

RDLC revue en lutte

\title{
RDLC en lutte
}

Auteur en lutte, Auteure en lutte et Camille Noûs

\section{OpenEdition}

\section{Journals}

Édition électronique

URL : http://journals.openedition.org/rdlc/7231

DOI : $10.4000 /$ rdlc.7231

ISSN : 1958-5772

Éditeur

ACEDLE

\section{Référence électronique}

Auteur en lutte, Auteure en lutte et Camille Noûs, "RDLC en lutte ", Recherches en didactique des langues et des cultures [En ligne], 17-1 | 2020, mis en ligne le 06 avril 2020, consulté le 18 avril 2020. URL : http://journals.openedition.org/rdlc/7231; DOI : https://doi.org/10.4000/rdlc.7231

Ce document a été généré automatiquement le 18 avril 2020

\section{(c) (1) $\odot$}

Recherches en didactique des langues et des cultures is licensed under a Creative Commons AttributionNonCommercial-NoDerivatives 4.0 International License 


\section{RDLC en lutte}

Auteur en lutte, Auteure en lutte et Camille Noûs

RÉSUMÉS

Article en lutte

INDEX

Mots-clés : revues en lutte, université ouverte, sciences en danger, RDLC 